\title{
UJI ANTIBAKTERI GEL EKSTRAK BATANG PEPAYA (Carica Papaya Linn.) SECARA IN VITRO TERHADAP Escherichia coli
}

\author{
Amalia Eka Putri $\left.{ }^{1 *}\right)$, Mia Audina Curnia Safitri ${ }^{1}$ \\ ${ }^{1}$ Program Studi S1 Farmasi, STIKes Karya Putra Bangsa, Tulungagung \\ Email: ekaputriamalia28@gmail.com
}

\begin{abstract}
Escherichia coli bacteria are pathogenic microorganisms that cause diarrhea, meningitis, and other infections. The case of antibiotic resistance resulted in the need for alternative therapies for antibacterial agents derived from plants with high potential as antibacterial agents, namely papaya stems. This study was conducted to determine the antibacterial activity of papaya stem extract gel against Escherichia coli. The research method uses experimental methods. The research sample was the papaya stalks which were macerated extraction with $96 \%$ ethanol solvent. The extract was made into a gel dosage with a concentration of 5\%. Papaya stem gel was tested for antibacterial with positive control, namely erythromycin and negative control, namely gel without extract. The results of the papaya stem gel antibacterial activity test showed that the papaya stem gel had antibacterial activity against Escherichia coli. The papaya stem extract gel preparation with a concentration of $5 \%$ had an average inhibition zone diameter of $19,23 \pm 0,50 \mathrm{~mm}$. The antibacterial activity is thought to come from the flavonoids, tannins, and saponins contained in the papaya stem fraction.
\end{abstract}

Keywords: Antibacterial, Carica papaya Linn., Escherichia coli ATCC 25922, Gel

\begin{abstract}
ABSTRAK
Bakteri Escherichia coli merupakan mikroorganisme patogen penyebab penyakit diare, meningitis, dan infeksi lainnya. Kasus resitensi antibiotik mengakibatkan diperlukannya terapi alternatif untuk agen antibakteri yang berasal dari tumbuhan dengan potensi tinggi sebagai antibakteri, yaitu batang pepaya. Penelitian ini dilakukan untuk mengetahui aktivitas antibakteri gel ekstrak batang pepaya terhadap Escherichia coli. Metode penelitian menggunakan metode eksperimental. Sampel penelitian adalah batang pepaya yang diekstraksi secara maserasi dengan pelarut etanol 96\%. Ekstrak dibuat sediaan gel dengan konsentrasi 5\%. Gel batang pepaya diuji antibakteri dengan kontrol positif yaitu eritromisin dan kontrol negatif yaitu gel tanpa ekstrak. Hasil uji aktivitas antibakteri gel batang pepaya menunjukkan bahwa gel batang pepaya mempunyai aktivitas antibakteri terhadap Escherichia coli. Sediaan gel ekstrak batang pepaya dengan konsentrasi 5\% mempunyai rata-rata diameter zona hambat sebesar 19,23 $\pm 0,50 \mathrm{~mm}$. Aktivitas antibakteri diperkirakan berasal dari senyawa flavonoid, tanin, dan saponin yang terkandung dalam fraksi batang pepaya.
\end{abstract}

Kata kunci: Antibakteri, Carica papaya Linn., Escherichia coli ATCC 25922, Gel 


\section{PENDAHULUAN}

Penyakit infeksi ini banyak diderita oleh masyarakat yang hidup di negara berkembang, seperti di Indonesia. Penyakit infeksi dapat menular dari satu individu ke individu lain yang pada umumnya diberikan terapi obat antibiotik (Huda, Putri, \& Sari, 2019). Antibiotik yang mulanya sensitif terhadap adanya mikroorganisme ini dapat berubah menjadi tidak sensitif, keadaan ini disebut dengan resistensi antibiotik (BPOM, 2014). Resistensi pada obat antibiotik ini dapat terjadi akibat beberapa faktor penyebab seperti penggunaan obat golongan antibiotik yang tidak tepat. Kasus resistensi terhadap obat-obatan antibiotik ini menyebabkan terjadinya peningkatan kebutuhan untuk mencari alternatif antibiotik lain, termasuk obat antibiotik yang berasal dari tumbuh-tumbuhan berkhasiat obat (Dewantari \& N., 2015). Pengenalan dan penggunaan tumbuhan berkhasiat obat oleh masyarakat Indonesia sering dilakukan sebagai salah satu upaya dalam menanggulangi permasalahan kesehatan yang sedang dihadapi (Suparni \& Wulandari, 2012).

Pepaya (Carica papaya Linn.) termasuk tanaman herba yang berasal dari famili Caricaceae yang berasal dari negara Amerika Tengah dan Hindia Barat, bahkan juga dari kawasan sekitar Mexico dan Costa Rica. Tanaman pepaya mempunyai bentuk dan susunan tubuh bagian luar yang termasuk kedalam tumbuhan perdu (Dey, 2012). Batang atau caulis dari tanaman pepaya merupakan suatu bagian yang penting sebagai tempat tumbuhnya tangkai daun dan tangkai buah. Bentuk dari batang tanaman pepaya ini yaitu bulat dengan permukaan batang yang mempunyai bekas-bekas tangkai daun (Agustina, 2017). Arah tumbuh dari batang tanaman pepaya yaitu tegak lurus keatas dengan permukaan batang yang memiliki tekstur licin, berongga, umumnya tidak memiliki cabang atau bercabang sedikit dan tumbuh dengan tinggi sekitar 5-10 meter (Dey, 2012).

Escherichia coli ATCC 25922 merupakan golongan bakteri Gram negatif yang berbentuk batang pendek, membentuk koloni yang bundar, cembung, halus dengan tepi yang nyata. Pertumbuhan bakteri ini optimum pada suhu $37^{\circ} \mathrm{C}$. Escherichia coli ATCC 25922 mempunyai beberapa antigen diantaranya yaitu antigen $\mathrm{O}$ (polisakarida), antigen $\mathrm{K}$ (kapsular), dan antigen $\mathrm{H}$ (flagella) (Atlas, 2010). Escherichia coli ATCC 25922 termasuk dalam kelompok bakteri heterotrof yang mendapatkan makanan dalam bentuk zat organik dari lingkungan sekitarnya karena bakteri jenis ini tidak mampu menyusun sendiri zat organik yang dibutuhkannya (Jawetz \& Adelberg's, 2012).

Gel adalah sediaan semipadat atau semisolid yang jernih, dapat tembus cahaya, dan mengandung zat aktif (Sugihartini \& Fujiastuti, 2015). Gel merupakan dispersi koloid yang memiliki kekuatan akibat oleh jaringan yang saling berikatan pada fase terdispersi (Dewantari \& N., 2015). Gel merupakan salah satu bentuk sediaan topikal yang masih banyak diminati konsumen maupun industri obat dan kosmestika (Katzung, Masters, \& Trevor, 2014). Gel memiliki kemampuan pelepasan obat yang baik, mudah dicuci, dan menimbulkan efek dingin pada kulit (Kaur \& Guleri, 2013). Berdasarkan uraian tersebut, maka penelitian ini perlu dilakukan untuk mengetahui aktivitas antibakteri dari gel ekstrak batang pepaya terhadap pertumbuhan bakteri Escherichia coli yang merupakan bakteri Gram negatif.

\section{BAHAN DAN METODE}

\section{Alat dan Bahan}

Alat yang digunakan dalam penelitian ini yaitu alat uji daya lekat, anak timbangan, autoklaf (GEA YX2808), ayakan mesh 80, botol maserasi, gelas objek, inkubator (model DNP Electro Thermal Incubator), lempeng kaca, kertas cakram, mikropipet, ose, oven, penggaris, pH universal, dan sudip.

Bahan yang digunakan dalam penelitian ini yaitu batang pepaya (Carica papaya Linn.) dalam kondisi segar sebanyak $5 \mathrm{~kg}$ yang diambil dari Blitar, Jawa Timur. Bahan lainnya yaitu asam asetat anhidrat, asam asetat glasial, asam klorida $(\mathrm{HCl})$, asam sulfat $\left(\mathrm{H}_{2} \mathrm{SO}_{4}\right)$, aquadestilata, $\mathrm{CMC}$, eritromisin, Escherichia coli ATCC 25922, etanol 96\% sebanyak $5000 \mathrm{~mL}$, gliserin, hydrogen 
peroksida, larutan ferri klorida $\left(\mathrm{FeCl}_{3}\right) 1 \%$, magnesium $(\mathrm{Mg})$, manitol salt agar (MSA), Mc Farland, $\mathrm{NaCl}$ fisiologis, nutrient agar (NA), nutrient broth (NB), dan propilen glikol.

\section{Metode}

\section{Pengambilan sampel}

Batang pepaya yang digunakan pada penelitian ini yaitu batang pepaya segar berumur 9-12 bulan yang terdapat di Blitar, Jawa Timur. Batang pepaya yang digunakan merupakan batang dengan kondisi baik.

2. Pembuatan simplisia

Batang pepaya yang telah selesai sortasi basah kemudian dirajang untuk mempercepat proses pengeringan. Pengeringan dilakukan dengan menggunakan oven suhu $40-50^{\circ} \mathrm{C}$. Simplisia kering kemudian diserbukkan dengan menggunakan blender dan di ayak dengan ukuran mesh 80 (Prasetyo \& Entang, 2013).

\section{Ekstraksi}

Proses ekstraksi dilakukan dengan metode maserasi. Serbuk simplisia batang pepaya sebanyak $500 \mathrm{~g}$ direndam dengan pelarut etanol $96 \%$ sebanyak $5 \mathrm{~L}$. proses ekstraksi dilakukan selama 5 hari dengan beberapa kali penggojokan pada suhu ruang. Ekstrak kemudian dipekatkan menggunakan oven suhu $40-50^{\circ} \mathrm{C}$ (Departemen Kesehatan RI, 2011).

4. Skrining fitokimia

a. Flavonoid

Ekstrak batang pepaya dilarutkan dengan $3 \mathrm{~mL}$ etanol kemudian dipanaskan dan disaring. Filtrat selanjutnya ditambah dengan $\mathrm{Mg} 0,1 \mathrm{~g}$ dan 2 tetes $\mathrm{HCL}$ pekat. Hasil positif mengandung flavonoid ditunjukkan dengan terbentuknya warna merah, orange, dan hijau (Baud, Sangi, \& Koleangan, 2014).

b. Tanin

Ekstrak batang pepaya dilarutkan dengan etanol kemudian ditambahkan dengan 2-3 tetes $\mathrm{FeCl}_{3}$ $1 \%$. Hasil positif mengandung tanin ditunjukkan dengan terbentuknya warna hitam kebiruan atau hijau (Dey, 2012).

c. Saponin

Ekstrak batang pepaya dilarutkan dengan $10 \mathrm{~mL}$ aquadestilata kemudian dididihkan dalam penangas air. Larutan sampel kemudian dikocok dan didiamkan selama 15 menit. Hasil positif mengandung saponin ditunjukkan dengan terbentuknya busa stabil (bertahan lama) (Dey, 2012).

\section{Pembuatan sediaan gel}

Gel ekstrak batang pepaya dibuat dengan konsentrasi 5\%. Pembuatan sediaan gel dimulai dengan preparasi bahan meliputi ekstrak batang pepaya, CMC, gliserin, propilenglikol, dan aquadestilata. Ekstrak batang pepaya sebanyak $5 \mathrm{~g}$ dilarutkan dalam sebagian aquadestilata yang telah dipanaskan pada suhu $50^{\circ} \mathrm{C}$. Larutan ekstrak ditambah dengan $\mathrm{CMC} 3 \mathrm{~g}$ dan diaduk sampai homogen. Selanjutnya ditambahkan gliserin $10 \mathrm{~mL}$, propilenglikol $5 \mathrm{~mL}$, dan aquadestilata sampai volume $100 \mathrm{~mL}$ dengan pengadukan secara kontinyu sampai terbentuk sediaan gel ekstrak batang pepaya. Formula gel ekstrak batang pepaya disajikan pada Tabel I. 
Tabel I. Formula gel ekstrak batang pepaya

\begin{tabular}{lc}
\hline Bahan & Jumlah \\
\hline Ekstrak Batang Pepaya & $5 \mathrm{~g}$ \\
CMC & $3 \mathrm{~g}$ \\
Gliserin & $10 \mathrm{~mL}$ \\
Propilenglikol & $5 \mathrm{~mL}$ \\
Aquadestilata ad & 100 \\
\hline
\end{tabular}

6. Evaluasi sediaan gel

a. Uji organoleptis

Uji organoleptis sediaan gel batang pepaya dilakukan secara visual dengan mengamati secara langsung bentuk, warna, dan bau dari sediaan. Sediaan gel yang baik yaitu berbentuk semisolid, jernih, dan berbau khas (Sugihartini \& Fujiastuti, 2015).

b. Uji $\mathrm{pH}$

Uji $\mathrm{pH}$ gel ekstrak batang pepaya dilakukan dengan menimbang sebanyak $1 \mathrm{~g}$ sediaan dan dilarutkan dalam $100 \mathrm{~mL}$ aquadestilata. $\mathrm{pH}$ sediaan diukur dengan indikator $\mathrm{pH}$ universal dengan pengulangan sebanyak 3 dan kemudian dihitung nilai rata-rata $\mathrm{pH}$ sediaan. Sediaan gel yang baik memiliki pH 5-6,5 (pH kulit) (Sugihartini \& Fujiastuti, 2015).

c. Uji homogenitas

Uji homogenitas sediaan gel ekstrak batang pepaya dilakukan dengan mengambil secukupnya sediaan dan diletakkan pada gelas objek. Selanjutnya sediaan diraba dan digosok. Massa gel homogen ditunjukkan dengan tidak adanya padatan atau butiran pada gelas objek (Sugihartini \& Fujiastuti, 2015).

d. Uji daya sebar

Uji daya sebar gel ekstrak batang pepaya dilakukan dengan meletakkan sebanyak $500 \mathrm{mg}$ gel pada kaca bulat berskala dan diletakkan kaca bulat lainnya diatas sediaan gel selama 1 menit. Diameter sediaan gel diukur, kemudian ditambah beban $50 \mathrm{~g}$ dan didiamkan selama 1 mneit. Hasi diemeter diukur, kemudian dilanjutkan penambahan beban secara berturut-turut $100 \mathrm{~g}, 150 \mathrm{~g}$, dan 200 g. gel yang baik memiliki daya sebar antara 5-7 cm (Sugihartini \& Fujiastuti, 2015).

e. Uji daya lekat

Gel ekstrak batang pepaya diletakkan diantara 2 gelas objek pada alat uji daya lekat. Selanjutnya ditekan dengan beban $1 \mathrm{~kg}$ selama 5 menit. Beban diangkat dan dilepaskan beban $80 \mathrm{~g}$ pada alat uji. Kemudian dicatat waktu pelepasan sediaan pada gelas objek. Gel yang baik memiliki waktu daya lekat lebih dari 4 detik (Sugihartini \& Fujiastuti, 2015).

f. Uji daya proteksi

Uji daya proteksi gel ekstrak batang pepaya dilakukan dengan mengoleskan sediaan gel pada kertas saring yang telah ditetesi dengan fenoftalein. Selanjutnya ditempelkan pada kertas saring lain dan ditetesi dengan larutan $\mathrm{KOH}$ 0,1 N. Hasil diamati pada waktu detik ke 15, 30, 45, 60, serta menit ke 3 dan 5 . Gel yang baik tidak akan memunculkan bercak merah pada kertas saring (Sugihartini \& Fujiastuti, 2015).

7. Uji aktivitas antibakteri

Uji aktivitas antibakteri gel ekstrak batang pepaya dilakukan dengan metode difusi cakram. Kertas cakram steril diresapi dengan gel ekstrak batang pepaya 5\%. Selanjutnya, diletakkan pada permukaan media yang telah diinokulasikan bakteri Escherichia coli ATCC 25922. Kontrol positif menggunakan eritromisin $0,01 \%$ dan kontrol negatif menggunakan basis gel tanpa ekstrak. Selanjutnya, diinkubasi pada suhu $37^{\circ} \mathrm{C}$ selama 24 jam. Hasil diamati dan diukur diameter zona hambat yang terbentuk. Data aktivitas antibakteri gel ekstrak batang pepaya kemudian dilakukan analisis statistik. 


\section{ANALISIS DATA}

Analisis data dilakukan dengan menggunakan SPSS 16 meliputi uji normalitas data, uji statistik non parametrik menggunakan uji Kruskal-Wallis yang dilanjutkan dengan uji MannWhitney. Pada penelitian ini digunakan taraf signifikansi $95 \%$.

\section{HASIL DAN PEMBAHASAN}

Determinasi tanaman batang pepaya menghasilkan data bahwa benar tanaman yang digunakan adalah tanaman pepaya (Carica papaya Linn.). Batang pepaya yang telah berbentuk serbuk simplisia dilakukan uji kadar air dengan hasil yaitu kadar air sebesar 8,7\% $(<10 \%)$. Simplisia yang baik harus memenuhi syarat kadar air yaitu harus kurang dari $10 \%$ agar simplisia tahan lama dalam proses penyimpanan karena reaksi enzimatik tidak dapat berlangsung (Prasetyo \& Entang, 2013). Simplisia batang pepaya yang telah dilakukan ekstraksi dengan menggunakan metode maserasi menghasilkan rendemen ekstrak sebesar 5,76\%. Hasil determinasi tanaman, uji kadar air, dan rendemen ekstrak disajikan pada Tabel II.

Tabel II. Hasil determinasi tanaman, uji kadar air, dan rendemen ekstrak

\begin{tabular}{lc}
\hline Perlakuan & Hasil \\
\hline Determinasi Tanaman & Batang Tanaman Pepaya (Carica papaya Linn.) \\
Uji Kadar Air Simplisia & $8,7 \%$ \\
Rendemen Ekstrak & $5,76 \%$ \\
\hline
\end{tabular}

Skrining fitokimia dilakukan pada ekstrak batang pepaya untuk mengetahui keberadaan senyawa metabolit sekunder yang terkandung dalam ekstrak tersebut. Batang tanaman pepaya memiliki kandungan senyawa aktif seperti saponin, tanin, dan flavonoid (Suparni \& Wulandari, 2012). Hasil skrining fitokimia ekstrak batang pepaya disajikan pada Tabel III.

Tabel III. Skrining Fitokimia

\begin{tabular}{lccc}
\hline \multirow{2}{*}{ Sampel } & \multicolumn{3}{c}{ Skrining Fitokimia } \\
\cline { 2 - 4 } & Flavonoid & Tanin & Saponin \\
\hline Ekstrak batang pepaya & $\sqrt{ }$ & $\sqrt{ }$ & $\sqrt{ }$ \\
\hline
\end{tabular}

Ekstrak batang pepaya kemudian diformulasikan menjadi sediaan gel ekstrak batang pepaya dengan konsentrasi 5\%. Sediaan gel ekstrak batang pepaya ditunjukkan pada Gambar 1. Evaluasi sediaan gel ekstrak batang pepaya dilakukan untuk mengetahui apakah sediaan gel ekstrak batang pepaya sudah sesuai dengan spesifikasi sediaan gel yang baik. Hasil evaluasi sediaan gel ekstrak batang pepaya disajikan pada Tabel IV.

Tabel IV. Evaluasi sediaan

\begin{tabular}{lccc}
\hline \multirow{2}{*}{ Evaluasi } & \multicolumn{3}{c}{ Hari ke- } \\
\cline { 2 - 4 } & 0 & $\mathbf{5}$ & $\mathbf{1 0}$ \\
\hline & Bau khas & Bau khas & Bau khas \\
Organoleptis & Semisolid & Semisolid & Semisolid \\
& Coklat & Coklat & Coklat \\
pH & 6 & 6 & 6 \\
Homogenitas & Homogen & Homogen & Homogen \\
Daya sebar & 5 & 5,1 & 5,2 \\
Daya lekat & 6,3 & 7,1 & 7,3 \\
Daya proteksi & Baik & Baik & Baik \\
\hline
\end{tabular}




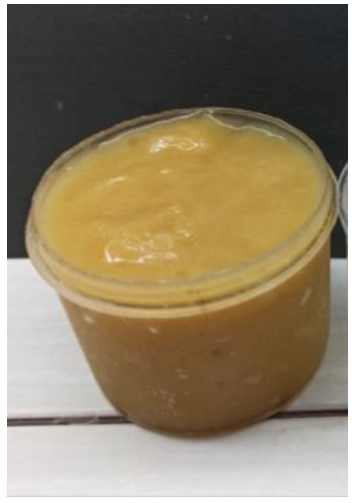

(A)

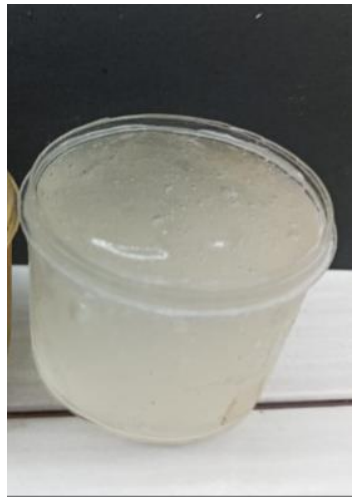

(B)

Gambar 1. (A) Gel Esktrak Batang Pepaya 5\% (B) Basis Gel Tanpa Esktrak

Evaluasi sediaan gel ekstrak batang pepaya meliputi uji organoleptis, uji $\mathrm{pH}$, uji homogenitas, uji daya sebar, uji daya lekat, dan uji daya proteksi. Evaluasi sediaan gel digunakan untuk memastikan sediaan telah sesuai dengan standar yang baik sehingga kandungan zat aktif dapat stabil dan efektif, seperti flavonoid, tanin, dan saponin yang diketahui dari hasil skrining fitokimia. Berdasarkan data hasil evaluasi sediaan, gel ekstrak batang pepaya mempunyai spesifikasi yang baik dan memenuhi persyaratan sediaan gel yang baik. Gel ekstrak batang pepaya kemudian diuji aktivitas antibakteri dengan menggunakan metode difusi cakram. Metode difusi cakram memiliki prinsip gel ekstrak batang pepaya yang terdapat pada kertas cakram akan berdifusi kedalam media yang telah dilakukan inokulasi bakteri Escherichia coli ATCC 2922, sehingga gel ekstrak batang pepaya akan menghambat pertumbuhan bakteri Escherchia coli ATCC 25922 dan menghasilkan diameter zona hambat (Jawetz \& Adelberg's, 2012). Hasil uji aktivitas antibakteri gel ekstrak batang pepaya (Carica papaya Linn.) disajikan pada Tabel V.

Tabel V. Uji aktivitas antibakteri gel ekstrak batang pepaya (Carica papaya Linn.)

\begin{tabular}{lcccc}
\hline \multirow{2}{*}{ No. Sampel } & \multicolumn{3}{c}{ Diameter Zona Hambat (mm) } & \multirow{2}{*}{ Rata-rata $(\mathrm{mm}) \pm \mathrm{SD}$} \\
\cline { 2 - 4 } & I & II & III & \\
\hline 1. Gel Ekstrak Batang Pepaya 5\% & 18,7 & 19,7 & 19,3 & $19,23 \pm 0,50$ \\
2. Kontrol Positif & 24 & 23,3 & 24 & $23,77 \pm 0,40$ \\
3. Kontrol Negatif & 0 & 0 & 0 & $0,00 \pm 0,00$
\end{tabular}

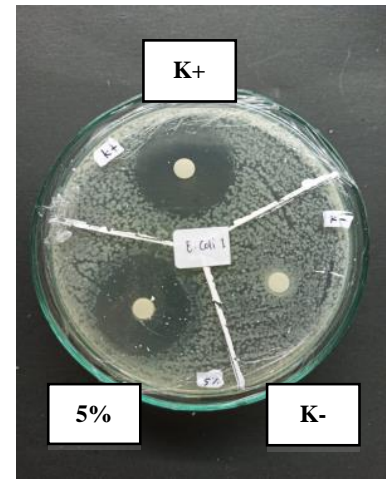

(A)

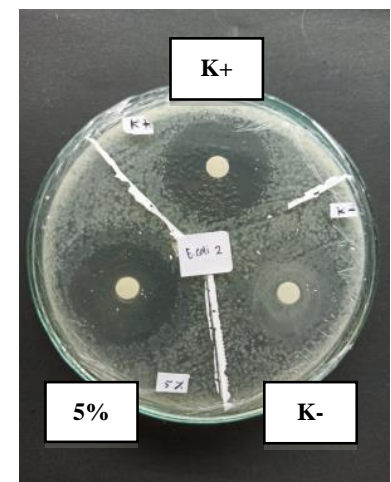

(B)

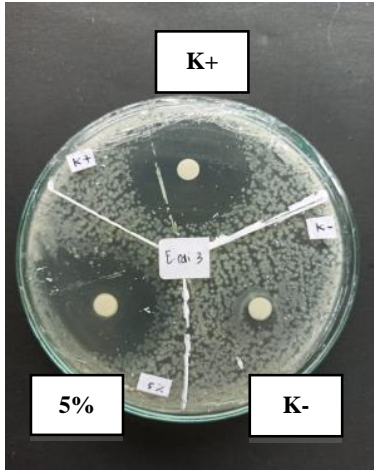

(C)

Gambar 2. Uji Antibakteri Gel Ekstrak Batang Pepaya 
Ket :

\section{(A) Replikasi I (B) Replikasi II (C) Replikasi III}

Hasil uji aktivitas antibakteri gel ekstrak batang pepaya dengan konsentrasi 5\% menunjukkan bahwa gel ekstrak batang pepaya memiliki aktivitas antibakteri terhadap bakteri Escherichia coli ATCC 2922 yang ditandai dengan adanya diameter zona hambat berupa daerah bening disekitar kertas cakram. Rata-rata diameter zona hambat untuk gel ekstrak batang pepaya $5 \%$ yaitu sebesar 19,23 $\pm 0,50 \mathrm{~mm}$ yang termasuk dalam kategori kuat. Kontrol positif yang digunakan yaitu eritromisin dengan konsentrasi $0,01 \%$ menghasilkan rata-rata diameter zona hambat sebesar 23,77 $\pm 0,40 \mathrm{~mm}$ yang termasuk dalam kategori sangat kuat. Aktivitas antibakteri gel ekstrak batang pepaya 5\% belum setara dengan kontrol positif. Hal tersebut terjadi karena eritromisin merupakan senyawa murni sehingga diperlukan konsentrasi ekstrak yang lebih besar untuk menghasilkan diameter zona hambat yang setara.

Hasil ini didukung dengan penelitian sebelumnya yang menyatakan bahwa ekstrak etanol batang pepaya pada konsentrasi $20 \%$ dan $25 \%$ mempunyai aktivitas sebagai antibakteri secara in vitro terhadap pertumbuhan bakteri Escherichia coli ATCC 25922. Zona hambat terhadap bakteri Escherichia coli ATCC 25922 yaitu sebesar 10,33 mm dan 10,83 mm yang termasuk dalam kategori sedang (Simbolon, Z., \& H., 2018).

Kontrol negatif yang berupa basis gel tanpa ekstrak menunjukkan hasil tidak ada zona hambat yang terbentuk. Hasil tersebut menandakan bahwa basis gel ekstrak batang pepaya tidak mempunyai aktivitas sebagai antibakteri terhadap Escherichia coli ATCC 2922.

Data hasil uji antibakteri gel ekstrak batang pepaya di analisis statistic dengan SPPS 16 menggunakan taraf signifikansi $95 \%$. Hasil menunjukkan signifikansi $<0,05$ yang berarti bahwa ada perbedaan yang signifikan antar kelompok perlakuan terhadap zona hambat yang dihasilkan pada bakteri Escherichia coli ATCC 2922. Aktivitas antibakteri gel ekstrak batang pepaya terhadap Escherichia coli ATCC 2922 dapat terjadi kemungkinan akibat adanya kandungan metabolit sekunder dalam ekstrak batang pepaya seperti senyawa flavonoid, tanin, dan saponin yang memiliki kemampuan sebagai agen antibakteri.

\section{KESIMPULAN}

Berdasarkan data hasil penelitian dan pembahasan, dapat disimpulkan bahwa gel ekstrak batang pepaya konsentrasi 5\% mempunyai aktivitas sebagai antibakteri terhadap bakteri Escherichia coli ATCC 2922 secara in vitro. Gel ekstrak batang pepaya konsentrasi 5\% menghasilkan rata-rata diameter zona hambat sebesar 19,23 $\pm 0,50 \mathrm{~mm}$ yang termasuk dalam kategori kuat.

\section{REFERENSI}

Agustina. 2017. Kajian Karakterisasi Tanaman Pepaya (Carica papaya L.) di Kota Madya Bandar Lampung, Skripsi, Jurusan Biologi Fakultas Matematika dan Ilmu Pengetahuan Alam Universitas Lampung.

Atlas, R.M. 2010. Handbook of Microbiological Media $4^{\text {th }} e d$. Washington, D.C.: CRC Press. Hal : 1469.

Badan Pengawasan Obat dan Makanan Republik Indonesia. 2014. Peraturan Kepala Badan Pengawas Obat dan Makanan Republik Indonesia Nomor 7 Tahun 2014 tentang Pedoman Uji Toksisitas Nonklinik Secara In Vitro. Jakarta : BPOM RI

Baud, G.S., Sangi, M.S., dan Koleangan, H.S.J. 2014. Analisis Senyawa Metabolit Sekunder dan Uji Toksisitas Ekstrak Etanol Batang Tanaman Patah Tulang (Euphorbia tirucalli L.) dengan Metode Brine Shrimp Lethality Test (BSLT). Journal Ilmiah Sains. Vol. 14(2). Hal. 106112.

Departemen Kesehatan Republik Indonesia. 2011. Suplemen II Farmakope Herbal Indonesia, Edisi I. Departemen Kesehatan RI. Jakarta. Hal. 110-111. 
Dewantari, D.R. dan Sugihartini, N. 2015, Formulasi dan Uji Aktivitas Gel Ekstrak Daun Petai Cina (Leucaena glauca, Benth) sebagai Sediaan Obat Luka Bakar. FARMASAINS, 2(5): 217-222.

Dey, P.M. 2012. Methods in Plant Biochemistry. Volume I. USA : Academic Press. Halaman 8182.

Huda, Choirul., Amalia Eka Putri., dan Devri Windi Sari. 2019. Uji Aktivitas Antibakteri Fraksi dari Maserat Zibethinus folium Terhadap Escherichia coli. Jurnal SainHealth, Vol.3, Hal.714.

Jawetz, Melnick \& Adelberg's. 2012. Mikrobiologi Kedokteran Edisi 25. Penerbit Buku Kedokteran EGC. Jakarta.

Kaur, L.P. and Guleri, T.K. 2013. Topical Gel: A Recent Approach for Novel Drug delivery, J.Biopharm.

Katzung, B.G., Masters, S.B., dan Trevor, A.J. 2014. Farmakologi Dasar dan Klinik. Volume 2. Edisi 12. Jakarta : EGC

Prasetyo \& Entang, 2013, Pengelolaan Budidaya Tanaman Obat-Obatan (Bahan Simplisia), Badan Penerbitan Fakultas Pertanian UNIB, Bengkulu.

Simbolon, M., Yelmira Z., dan Faizal H. 2018. Pembuatan Sabun Transparan dengan Penambahan Ekstrak Batang Pepaya Sebagai Antibakteri. Chempublish Journal, Vol.3, Hal. 57-68.

Sugihartini, N., Fujiastuti, T., 2015. Sifat Fisik dan Daya Iritasi Gel Ekstrak Etanol Herba Pegagan (Centella asiatica L) dengan Variasi Jenis Gelling Agent. Pharmacy. 12. Hal, 11-20.

Suparni, Ibunda dan Wulandari. 2012. Herbal Nusantara : 1001 Ramuan Tradisional Asli Indonesia. Rapha Publishing. Yogyakarta. 